\title{
Hydrogen sulfide impairs keratinocyte cell growth and adhesion inhibiting mitogen-activated protein kinase signaling
}

\author{
Giuliana Gobbi ${ }^{1,2,5}$, Francesca Ricci ${ }^{1,5}$, Chiara Malinverno ${ }^{1}$, Cecilia Carubbi ${ }^{1}$, Maurizia Pambianco ${ }^{3}$, \\ Giuseppe de Panfilis ${ }^{4}$, Marco Vitale ${ }^{1,2}$ and Prisco Mirandola ${ }^{1,2}$
}

The effects of exogenous hydrogen sulfide $\left(\mathrm{H}_{2} \mathrm{~S}\right)$ on normal skin-derived immortalized human keratinocytes have been investigated in detail. We show in vitro that exogenous hydrogen sulfide reduces clonal growth, cell proliferation and cell adhesion of human keratinocytes. $\mathrm{H}_{2} \mathrm{~S}$, in fact, decreases the frequency of the putative keratinocyte stem cell subpopulation in culture, consequently affecting clonal growth, and impairs cell proliferation and adhesion of mature cells. As a mechanistic explanation of these effects, we show at the molecular level that (i) $\mathrm{H}_{2} \mathrm{~S}$ reduces the Raf/MAPK kinase/ERK signaling pathway; (ii) the reduced adhesion of sulfur-treated cells is associated to the downregulation of the expression of $\beta 4, \alpha 2$ and $\alpha 6$ integrins that are necessary to promote cell adhesion as well as anti-apoptotic and proliferative signaling in normal keratinocytes. One specific interest of the effects of sulfurs on keratinocytes derives from the potential applications of the results, as sulfur is able to penetrate the skin and a sulfur-rich balneotherapy has been known for long to be effective in the treatment of psoriasis. Thus, the relevance of our findings to the pathophysiology of psoriasis was tested in vivo by treating psoriatic lesions with sulfurs at a concentration comparable to that most commonly found in sulfurous natural springs. In agreement with the in vitro observations, the immunohistochemical analysis of patient biopsies showed a specific downregulation of ERK activation levels, the key molecular event in the sulfur-induced effects on keratinocytes.

Laboratory Investigation (2009) 89, 994-1006; doi:10.1038/labinvest.2009.61; published online 22 June 2009

KEYWORDS: flow cytometry; western blot; MAPK; skin; NaHS

Hydrogen sulfide $\left(\mathrm{H}_{2} \mathrm{~S}\right)$ - known for decades as a toxic gasis endogenously generated from cysteine, in reactions catalyzed by cystathionine $\beta$-synthase (CBS) and cystathionine $\gamma$ lyase (CSE). ${ }^{1-4}$ Mounting data on endogenously generated $\mathrm{H}_{2} \mathrm{~S}$ have now included this gas in the family of gasotransmitters, together with nitric oxide $(\mathrm{NO})$ and carbon monoxide (CO), and the variety of its effects start to be understood both at the cellular and molecular levels. ${ }^{5} \mathrm{Al}-$ though a physiological role in hippocampal neurons longterm potentiation has also been shown, ${ }^{6}$ perhaps the best characterized physiological effect of $\mathrm{H}_{2} \mathrm{~S}$ to date is the relaxation of vascular smooth muscle cells, generated by $\mathrm{H}_{2} \mathrm{~S}$ mediated $\mathrm{K}_{\text {ATP }}$ channel opening. ${ }^{7,8}$ However, NaHS also impairs aortic vascular smooth muscle cell proliferation by interfering with mitogen-activated protein kinase (MAPK) activation. ${ }^{9} \mathrm{H}_{2} \mathrm{~S}$ can induce an upregulation of antiinflammatory and cytoprotective genes including heme oxygenase-1 (HMOX1) ${ }^{10,11}$ cytochrome $c$ oxidase subunit $\mathrm{v}$, vascular endothelial growth factor (VEGF), insulin-like growth factor (IGF) receptor and several genes associated with the transforming growth factor- $\beta$ (TGF- $\beta$ ) receptor pathway. ${ }^{12}$ Besides, experimental data in animals show that an enhanced production of endogenous $\mathrm{H}_{2} \mathrm{~S}$ contributes to the pathophysiology of the organ injury associated with sepsis and shock. ${ }^{13,14}$

Pharmacological effects of $\mathrm{H}_{2} \mathrm{~S}$ are essentially related to two distinct mechanisms: first, the ability to activate/open membrane $\mathrm{K}_{\mathrm{ATP}}$ channels ${ }^{7}$ and second, and the modulation

\footnotetext{
Department of Anatomy, Pharmacology and Forensic Medicine, University of Parma, Parma, Italy; ${ }^{2}$ Center for Morphology and Body Composition (CMBC), University of Parma, Parma, Italy; ${ }^{3}$ Terme di Sirmione, Cell Biology Laboratory, Terme di Sirmione, Brescia, Italy and ${ }^{4}$ Department of Surgery, Dermatology Division, University of Parma, Parma, Italy

Correspondence: Professor M Vitale, MD, Department of Anatomy, Pharmacology and Forensic Medicine, University of Parma, via Gramsci 14, Ospedale Maggiore, Parma 43100, Italy. E-mail: marco.vitale@unipr.it

${ }^{5 *}$ These authors equally contributed to this work. 
of gene transcription by the activation of different signaling pathways. Many studies, focused on myocardial protection, have shown the cardioprotective effects of $\mathrm{H}_{2} \mathrm{~S}$ in in vitro and in vivo experiments. ${ }^{15}$ Although the mechanism of this protection is-at least in part-related to the ability of $\mathrm{H}_{2} \mathrm{~S}$ to activate myocardial $\mathrm{K}_{\mathrm{ATP}}$ channels, the extracellular signal-regulated protein kinase (ERK), phosphatidylinositol 3-kinase (PI3K)/Akt and protein kinase C (PKC) pathways seem to be involved as well. ${ }^{16,17}$ Different intracellular signaling pathways produce a combination of anti-apoptotic and anti-inflammatory effects based on the inhibition of caspase 9, p38 MAPK and c-Jun N-terminal kinase (JNK) activation, as well as of NF- $\kappa \mathrm{B}$ nuclear traslocation and leukocyte accumulation in infarct areas. ${ }^{18}$ Recently, however, it has been reported that in pancreatic acinar cells the activation of ERKs promotes cell survival, whereas the activation of JNKs and p38 MAPK leads to $\mathrm{H}_{2} \mathrm{~S}$-induced apoptosis. ${ }^{19}$ We have shown that NaHS promotes the survival of cultured granulocytes: the delayed onset of granulocytes apoptosis in the presence of $\mathrm{H}_{2} \mathrm{~S}$ is mediated by the inhibition of caspase-3 cleavage and p38 phosphorylation. ${ }^{20}$ Furthermore, differently from what observed on granulocytes, we also showed that $\mathrm{H}_{2} \mathrm{~S}$ exerts a subset-specific toxicity on peripheral blood lymphocytes that die by a caspase independent mechanism of necrosis after a rapid loss of mitochondrial membrane potential, and not by apoptosis. Functionally, the surviving lymphocytes show a decreased proliferative capacity in response to phytohemagglutinin (PHA) and interleukin-2 (IL-2), natural killer (NK) cells show a decreased spontaneous cytotoxicity against tumor target cells and both CD8 and CD4 T cells produce less IL-2 during activation. ${ }^{21}$ These observations together with the known anti-inflammatory activity of $\mathrm{H}_{2} \mathrm{~S}$ sound relevant to understand some earlier unexplained biological effects exerted by sulfur therapy.

$\mathrm{H}_{2} \mathrm{~S}$ effects on the cell viability, proliferation, activation, cytokine secretion and cell adhesion have been investigated in many different cell types (lymphocytes, granulocytes, macrophages, fibroblasts, smooth muscle cells, myoblasts, cardiomyocytes, neuroblastoma, neurons, astrocytes, epatocytes, endothelial cells, colon cancer cells and intestinal epithelial cells). ${ }^{15}$ However, the effects promoted by exogenous $\mathrm{H}_{2} \mathrm{~S}$ on keratinocytes and/or skin-derived blasts have been poorly investigated. The specific interest derives from the potential applications of the results, as sulfur is able to penetrate the skin and a sulfur-rich balneotherapy, known to be effective in the treatment of psoriasis, ${ }^{22}$ might turn useful also in other T-cell-mediated autoimmune diseases of the skin.

Thus, we have studied here the effects of exogenous $\mathrm{H}_{2} \mathrm{~S}$ on the cell growth of normal skin-derived immortalized human keratinocytes. $\mathrm{H}_{2} \mathrm{~S}$ was used at concentrations comparable to those found in natural sources. We show that $\mathrm{H}_{2} \mathrm{~S}$ decreases the frequency of the putative keratinocyte stem cell subpopulation in culture, consequently affecting clonal growth and impairs cell proliferation and adhesion of mature cells. As a mechanistic explanation of these effects, we show at the molecular level that (i) $\mathrm{H}_{2} \mathrm{~S}$ reduces the Raf/MAPK kinase/ ERK signaling pathway, and (ii) the reduced adhesion of sulfur-treated cells is associated to the down-regulation of the expression of $\beta 4, \alpha 2$ and $\alpha 6$ integrins that are necessary to promote cell adhesion as well as anti-apoptotic and proliferative signaling in normal keratinocytes. ${ }^{23-25}$

\section{MATERIALS AND METHODS Cell Cultures}

Normal skin-derived immortalized human keratinocytes, clone NCTC 2544, were obtained from the American Tissue Culture Collection and cultured in EMEM medium (Euroclone, West York, UK) containing $10 \%$ fetal calf serum, penicillin $(100 \mathrm{U} / \mathrm{ml})$, streptomycin $(100 \mu \mathrm{g} / \mathrm{ml})$, and L-glutamine $(2 \mathrm{mM})$. Cells were passaged two or three times weekly at ratios between 1:5 and 1:10. Cell cultures were routinely assayed for mycoplasm contamination by Mycoalert mycoplasm detection kit (Lonza, Rockland, ME).

\section{Cell Treatment}

NaHS salt (Sigma-Aldrich, St. Louis, MO) was dissolved in $50 \mathrm{ml}$ of RPMI medium at the concentration of $400 \mathrm{mM}$. Stock solution was stored for 1 week at $4^{\circ} \mathrm{C}$. Immediately before experiments, stock solution was diluted in the cell culture medium at the final indicated concentration.

Cells were treated with U0126 $(10 \mu \mathrm{M})$, LY294002 $(60 \mu \mathrm{M})$, SB202190 $(30 \mu \mathrm{M})$, SP600125 $(10 \mu \mathrm{M})$ (Calbiochem, La Jolla, CA) to induce ERK-1/-2, PI3K, p38 and SAPK/JNK irreversible inhibition before start of the experiments. When used in combination with NaHS, U0126, LY294002, SP600125 and SB202190 were added to cell medium $30 \mathrm{~min}$ before NaHS. Phosphatases activity was inhibited pretreating cells with okadaic acid (Sigma-Aldrich). Different concentrations of okadaic acid were used in different functional assays to minimize its toxic effect: $100 \mathrm{nM}$ in short-time cultures (adhesion and cell proliferation assays), $10 \mathrm{nM}$ in long-time cultures (colony formation assay). Equal volumes of DMSO were added to control samples.

\section{Colony Formation Assay}

Exponentially growing NCTC cells were seeded at 500 cells/ well in 6-well plates or in $2.5 \mathrm{~cm}$ Petri dishes and treated with or without $\mathrm{H}_{2} \mathrm{~S}$. After 7 days of growth, cells were fixed and stained with 1/10 Giemsa/ PBS. Total colonies were scored, in particular, colonies greater than 50 cells were considered as holoclones, derived from the stem cell subpopulation. ${ }^{26}$ Colonies of less than 30 cells were not scored (satellite/ abortive colonies). For each treatment, six individual wells were scored by two independent trained observers.

\section{Flow Cytometry Analysis}

To assess the cell surface expression of $\alpha 2, \alpha 3, \alpha 5, \alpha 6, \beta 3, \beta 4$ integrins, aliquots of $0.3 \times 10^{6}$ cells were labeled with antiCD49b, anti-CD49c, anti-CD49e, anti-CD49f, anti-CD104, 
anti-CD61 RPE or FITC-conjugated mAbs (BD Bioscience, San Jose, CA). Untreated and $2 \mathrm{mM}$ NaHS-treated cells were grown for $24 \mathrm{~h}$, trypsinized and incubated for $1 \mathrm{~h}$ at $4{ }^{\circ} \mathrm{C}$ with the reported antibodies. In some experiments, the absolute number of surface antigens expressed/cell was calculated. To this purpose, the flow cytometer was calibrated with a set of standardized beads (DAKO, Glostrup, Denmark) each with a known amount of fluorochrome (either FITC or RPE) expressed in units of MESF (molecules of equivalent soluble fluorescein). Thus, a standard curve was constructed by plotting the beads MESF values against the median channel in which the fluorescence sample peak was displayed. ${ }^{27}$ Analysis of the samples was performed by an Epics XL flow cytometer (Beckman Coulter) and the Expo ADC software (Beckman Coulter).

\section{Assessment of Apoptosis}

Cell culture viability was assessed by trypan blu exclusion. Apoptotic cells were identified by flow cytometry either as subdiploid peaks generated by DNA fragmentation or by annexin V/propidium iodide (PI) staining. Specifically, cells were permeabilized by ethanol in the presence of RNAse $\mathrm{H}$ buffer and stained with $20 \mu \mathrm{g} / \mathrm{ml}$ of PI, or phosphatidylserine was stained by FITC conjugate annexin V (ACTIPLATE, Valter Occhiena, Torino, Italy) in $\mathrm{Ca}^{2+}$ and $2.5 \mu \mathrm{g} / \mathrm{ml} \mathrm{PI}$ staining buffer, following manufacturer's protocol.

\section{Cell-Cycle Analysis}

NCTC adherent cells were trypsinized, washed with PBS and permeabilized in $70 \%(\mathrm{v} / \mathrm{v})$ ethanol/PBS solution at $4{ }^{\circ} \mathrm{C}$ for at least $24 \mathrm{~h}$. Cells were washed with PBS and DNA was stained with $20 \mu \mathrm{g} / \mathrm{ml}$ of PI and $100 \mu \mathrm{g} / \mathrm{ml}$ of RNAse in PBS, at room temperature for $30 \mathrm{~min}$. Standard distribution of cell-cycle phases and percentages of apoptotic cells were evaluated as described earlier. ${ }^{28}$ To minimize the inter-experimental variations observed in the cell-cycle analysis of synchronized NCTC cells, relative progression in S phase was expressed as follows:

$$
100 *\left[\% \mathrm{ST}_{14 \mathrm{~h}}-\% \mathrm{ST}_{x}\right] /\left[\% \mathrm{ST}_{14 \mathrm{~h}}-\% \mathrm{ST}_{0}\right]
$$

where $\% \mathrm{ST}_{14 \mathrm{~h}}=$ percentage of cells in $\mathrm{S}$ phase $14 \mathrm{~h}$ after serum addition (maximal S level); $\% \mathrm{ST}_{0}=$ percentage of cells in $S$ phase after serum starvation (minimum $S$ level); $\% \mathrm{ST}_{x}=$ percentage of cells in $\mathrm{S}$ phase at time $x$ from stimulation.

Similarly, relative progression in G2/M cell-cycle phase was reported as follows:

$100 *\left[\% \mathrm{G}_{2} / \mathrm{MT}_{6 \mathrm{~h}}-\% \mathrm{G} 2 / \mathrm{MT}_{x}\right] /\left[\% \mathrm{G}_{2} / \mathrm{MT}_{6 \mathrm{~h}}-\% \mathrm{G} 2 / \mathrm{MT}_{0}\right]$

where $\% \mathrm{G}_{2} / \mathrm{MT}_{6 \mathrm{~h}}=$ maximal $\mathrm{G} 2 / \mathrm{M}$ level; $\% \mathrm{G} 2 / \mathrm{MT}_{0}=$ minimum G2/M level.

\section{BRDu Incorporation}

Cell proliferation was quantified by the analysis of BrdU incorporation by time-resolved fluorometry. Newly synthesized DNA was detected using europium (Eu)-labeled anti-BrdU monoclonal antibody (DELFIA cell proliferation assay kit, Perkin Elmer, Waltham, MA). Briefly, $1 \times 10^{5}$ cells were grown for 2 or $24 \mathrm{~h}$ at $37^{\circ} \mathrm{C}$ in $200 \mu \mathrm{l}$ of culture medium in 96-well plates in the presence of $10 \mu \mathrm{M} \mathrm{BrdU}$. After cell fixation and DNA denaturation, cell were labeled with anti-BrdU-Eu for $1 \mathrm{~h}$ at $4^{\circ} \mathrm{C}$, washed and DELFIA inducer was added to dissociate Eu ions, forming fluorescent chelates. Eu-fluorecence was finally measured in a time-resolved fluorometer 1420 Victor- ${ }^{3} \mathrm{~V}$ (Perkin Elmer).

\section{Plastic Adhesion Assay}

Cells were collected, counted and resuspended in EMEM complete medium at the concentration of $5 \times 10^{6} \mathrm{cells} / \mathrm{ml}$, in the presence or absence of $2 \mathrm{mM} \mathrm{NaHS}$. Then, cells were immediately seeded in 6-well plastic plates and allowed to adhere for $24 \mathrm{~h}$. Medium was then collected and cell monolayer was gently washed with complete medium to recover all floating cells. Adherent cells were then collected by trypsinization. Adherent cells (adherent fraction culture, AFC) and floating cells (floating fraction culture, FFC) were resuspended in $500 \mu \mathrm{l}$ of fresh medium: cell viability, apoptosis and cell concentration of AFC and FFC were analyzed by flow cytometry (Cell Lab Quanta, Beckman Coulter). Cell viability was expressed as percentage of annexin ${ }^{-} \mathrm{PI}^{-}$cells.

\section{Western Blot}

Cells were collected and washed with ice-cold PBS containing

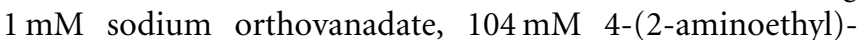
benzenesulfonyl fluoride, $0.08 \mathrm{mM}$ aprotinin, $2 \mathrm{mM}$ leupeptin, $4 \mathrm{mM}$ bestatin, $1.5 \mathrm{mM}$ pepstatin A, $1.4 \mathrm{mM}$ E-64. Cells were then lysed in Triton lysis buffer. Protein concentration was determined using a BCA protein assay kit (Pierce, Rockford, IL). Aliquots of total protein samples $(50 \mu \mathrm{g})$ were blotted using antibodies specific for phosphorylated (Thr202/Tyr204) ERK-1/ERK-2 MAPKs (1:1000), phosphorylated (Ser259) Raf (1:1000), phosphorylated Akt (ser473) (1:1000), phosphorylated GSK-3 $\beta$ (ser9) (1:1000). A measure of $100 \mu \mathrm{g}$ of protein was used for phospho-MAPK kinase (MEK)1/2 (Ser217/221) (1:1000 dilution), phosphoSAPK/JNK (Thr183/Tyr185) (1:1000) and phospho-p38 (Thr180/Tyr182) (1:1000) detection. Incubation times and washing buffers were chosen as indicated by manufacturers' protocols (Cell Signaling Technology Inc., Danvers, MA). Anti- $\beta$-actin (Sigma) mAb was diluted 1:5000. Filters were finally washed and incubated for $1 \mathrm{~h}$ at room temperature with anti-rabbit $(1: 2000)$ or anti-mouse (1:2000) peroxidase-conjugated secondary antibodies, and revealed by Enhanced Chemiluminescence western blotting detection reagent (Amersham Biosciences, GE Healthcare UK Ltd, 
a

Control

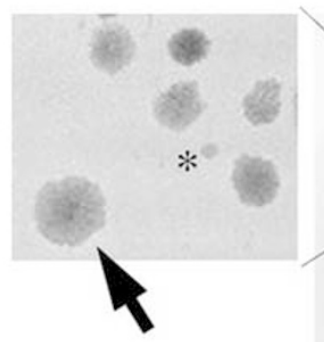

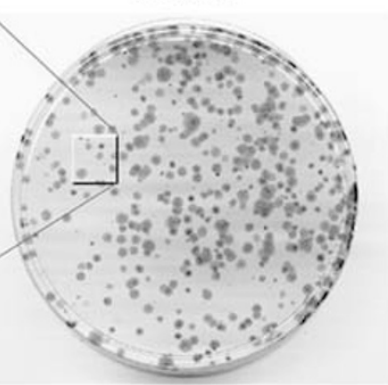

NaHS

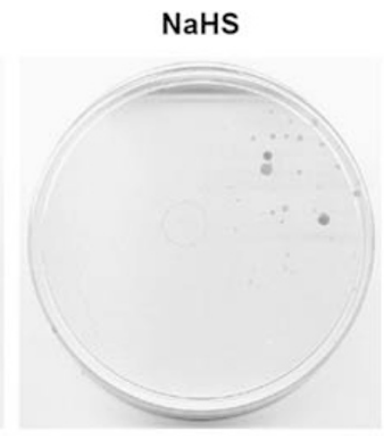

b
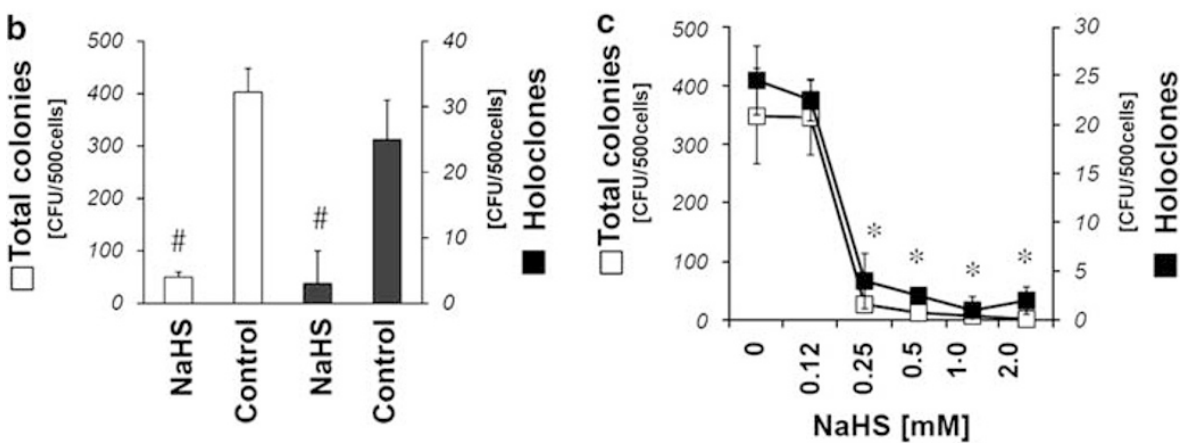

Figure $1 \mathrm{H}_{2} \mathrm{~S}$ impairs NCTC cell growth. (a) NCTC cells treated with or without (control) 2 mM NaHS and assayed for colony formation. Insert shows six total scored colonies and one holoclone (arrow). Abortive/satellite colonies were not scored ( $* 30$ cells). (b) Number of holoclones and normal colonies

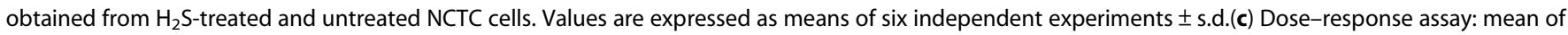
four independent experiments $\pm \mathrm{s}$.d. is reported. ${ }^{\star} P<0.05$ Anova-Dunnet's test ( $v s$ untreated cells); $P<0.05 t$-test ( $v s$ control cells).

Buckinghamshire, UK). The membranes were then stripped and re-probed with $\beta$-actin for protein loading control.

\section{Patient Treatment and Immunohistochemistry}

One voluntary, 70-year-old male patient affected by psoriasis was treated with $\mathrm{NaHS}(2 \mathrm{mM}$ in sterile $0.9 \%$ salt water) or saline alone as negative control. A measure of $10 \mathrm{ml}$ of NaHS solution was applied to a psoriatic plaque lesion on the left gluteus skin for $15 \mathrm{~min} /$ day for 7 days consecutively. As negative control, a similar lesion on the right gluteus was treated with saline solution alone. At the end of the treatment, biopsies from both skin areas were collected. As a further negative control, a biopsy was obtained from a normal skin region of the gluteus. Detailed informed consensus was obtained from the patient before the procedure.

Biopsies were fixed in $10 \%$ formalin, and embedded in paraffin. ${ }^{29-31}$ Paraffin blocks were serially cut into $5 \mathrm{~mm}$ sections and serial sections from each specimen were routinely stained with hematoxylin-eosin for histological examination.

Sections were independently stained to detect pERK, pRaf- 1 and pp38 pp38 (Cell Signaling Technology). All sections were dewaxed with xylene and re-hydrated by passages through decreasing concentrations of ethanol (from 100 to $80 \%$ ). Endogenous peroxidase activity was blocked by a $30 \mathrm{~min}$ incubation at room temperature with methanol containing
$3 \% \mathrm{H}_{2} \mathrm{O}_{2}$. Sections were then microwaved in a citrate solution $(\mathrm{pH} 6.0)$ at $750 \mathrm{~W}$ for $10 \mathrm{~min}$. After rinsing in Tris buffered saline (TBS; pH 7.4), sections were preincubated for $30 \mathrm{~min}$ at room temperature with normal rabbit serum or normal goat serum diluted 1:5, before incubation in a humidified chamber for $90 \mathrm{~min}$ at room temperature with mAbs. Sections were then washed twice in TBS and incubated for 30 min with diluted biotinylated secondary antibody solution (Vector Laboratories Inc., Burlingame, CA, USA). At the end of incubation, sections were then washed again in TBS and incubated for another $30 \mathrm{~min}$ at room temperature with Vectastain Elite ${ }^{\circledR}$ ABC reagent (Vector Laboratories). Peroxidase activity was detected by incubating tissue sections for 10-15 min with a solution of 3-3-diaminobenzidine (DAB) $(500 \mu \mathrm{LAB}(2.5 \%)$ in $50 \mathrm{ml}$ TBS; Sigma) in the presence of $50 \mu \mathrm{l} 30 \% \mathrm{H}_{2} \mathrm{O}_{2}$. Sections were finally counterstained with Mayer's hemalum (Sigma). Negative controls were treated in parallel, using isotype-matched irrelevant antibodies as first step reagents.

\section{RESULTS}

\section{$\mathrm{H}_{2} \mathrm{~S}$ Impairs Cell Proliferation}

On the basis of what we showed earlier on the effects of $\mathrm{H}_{2} \mathrm{~S}$ on lymphocytes and granulocytes, NaHS was added to NCTC culture medium to the concentration of $2 \mathrm{mM}$. Similarly to what observed in lymphocytes, the growth of NCTC cells was 

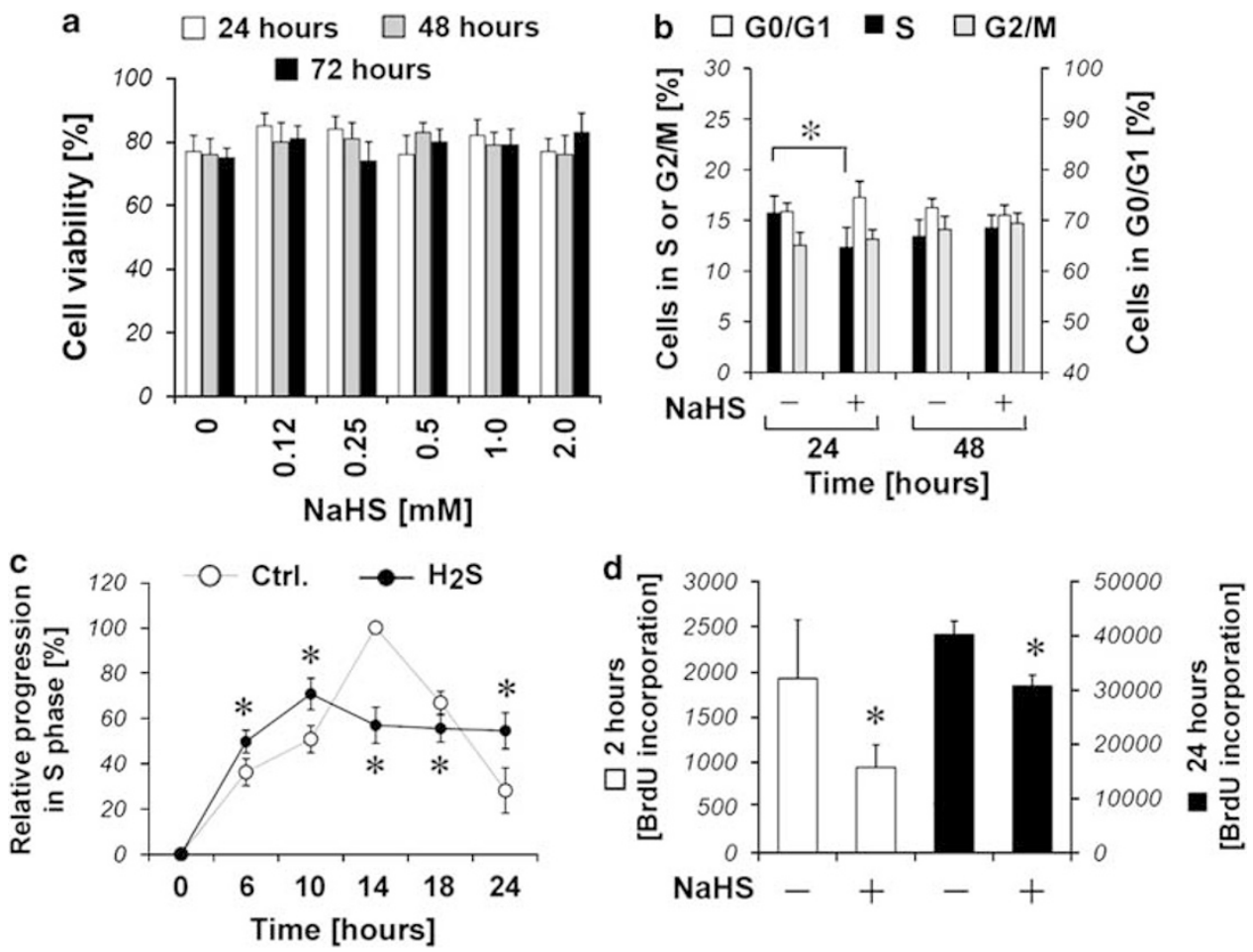

Figure 2 NaHS affects cell viability and proliferation. (a) Cultures of confluent NCTC cells were treated with different concentrations of NaHS for the indicated times. Cell viability was analyzed by flow cytometry staining cells with annexin $\mathrm{V}$ and $\mathrm{PI}$. (b) $\mathrm{H}_{2} \mathrm{~S}$ impairs cell proliferation of nonsynchronized cells. Proliferating NCTC cells were treated for the indicated times with (+) or without (-) 2 mM NaHS. Distributions among G0/G1 (empty bar), S (black bar) and G2/M (gray bar) cell-cycle phases are indicated as means \pm s.d. of four independent experiments. (c) Cell-cycle analysis: starved NCTC cells were cultured for the indicated times with $20 \% \mathrm{FBS}$ and $\mathrm{NaHS}$. $\mathrm{H}_{2} \mathrm{~S}$-treated cells (solid circles) and untreated cells (empty circles, control culture) were analyzed by flow cytometry: the number of cells in S phase is reported. (d) DNA synthesis of nonsynchronized NCTC cells. Short treatment ( $2 \mathrm{~h}$, black bar) and long treatment $\left(24 \mathrm{~h}\right.$, empty bar) with NaHS $(2 \mathrm{mM})$ both reduced BudU incorporation. Means of four experiments $\pm \mathrm{s} . \mathrm{d}$. ${ }^{\star} P<0.05$-test (treated vs untreated cells).

impaired by NaHS. The analysis of the number and the morphology of the colonies [see Ref. 26] revealed that both the number of holoclones (generated by cancer stem cell pool) and that of normal colonies are significantly reduced by a single dose of NaHS added to the cell culture $24 \mathrm{~h}$ after seeding (Figure 1a and b). Dose-response experiments (Figure 1c) show that NaHS is able to prevent colony formation at $250 \mu \mathrm{M}$, reaching the maximal effect at $500 \mu \mathrm{M}$. We first asked whether the reduced number of colonies was due to $\mathrm{H}_{2} \mathrm{~S}$-induced cell death. Figure $2 \mathrm{a}$ shows that the viability of a confluent monolayer of NCTC cells is not affected even after $72 \mathrm{~h}$ of $\mathrm{H}_{2} \mathrm{~S}$ treatment, suggesting that $\mathrm{H}_{2} \mathrm{~S}$ toxicity is not significantly implicated in the observed reduction in colony formation.

The formation of a colony is, however, also strongly dependent on cell proliferation, which therefore was initially studied by cell-cycle analysis in semiconfluent cell cultures treated with $2 \mathrm{mM} \mathrm{NaHS}$ for 24 and $48 \mathrm{~h}$. NaHS reduced the $\mathrm{S}$ phase (Figure 2b) of nonsynchronized cells after $24 \mathrm{~h}$ of treatment. To study in greater detail the effects of $\mathrm{H}_{2} \mathrm{~S}$ on cell proliferation, we then synchronized NCTC cell cultures by serum starvation. A measure of $20 \%$ FBS was added to starving cells to restart proliferation. As shown in Figure 2c, control cells showed the maximal S-phase frequency $14 \mathrm{~h}$ after serum addition. NaHS-treated cells anticipated S-phase entry, and the $S$ phase itself was prolonged; however, the overall number of S-phase cells was significantly reduced in the treated cultures, which accumulated in G2/M. Thus, as expected, the analysis of BrdU incorporation in nonsynchronized cell cultures showed that $2 \mathrm{mM} \mathrm{NaHS}$ impaired DNA synthesis (Figure 2d) as early as $2 \mathrm{~h}$ of treatment $(50.1 \pm 10.1 \%$ reduction) and that the inhibition persisted for $24 \mathrm{~h}$.

\section{$\mathrm{H}_{2} \mathrm{~S}$ Impairs Cell Adhesion}

As adhesion to substrates can modulate the proliferation of epithelial cells, we subsequently asked whether sulfurs could interfere with NCTC cell adhesion. Cells were therefore allowed to seed in the presence or absence of different concentrations of NaHS; $24 \mathrm{~h}$ later, floating cells were collected and counted, and the viability of the remaining adherent cells was evaluated by flow cytometry. NaHS induced a dosedependent reduction in cell adhesion to the plastic of Petri dishes (Figure 3a) and of cell viability of adherent cells (Figure 3b). In particular, in the presence of $2 \mathrm{mM} \mathrm{NaHS}$, $41.0 \pm 12.1 \%$ of the seeded cells detached, whereas only 

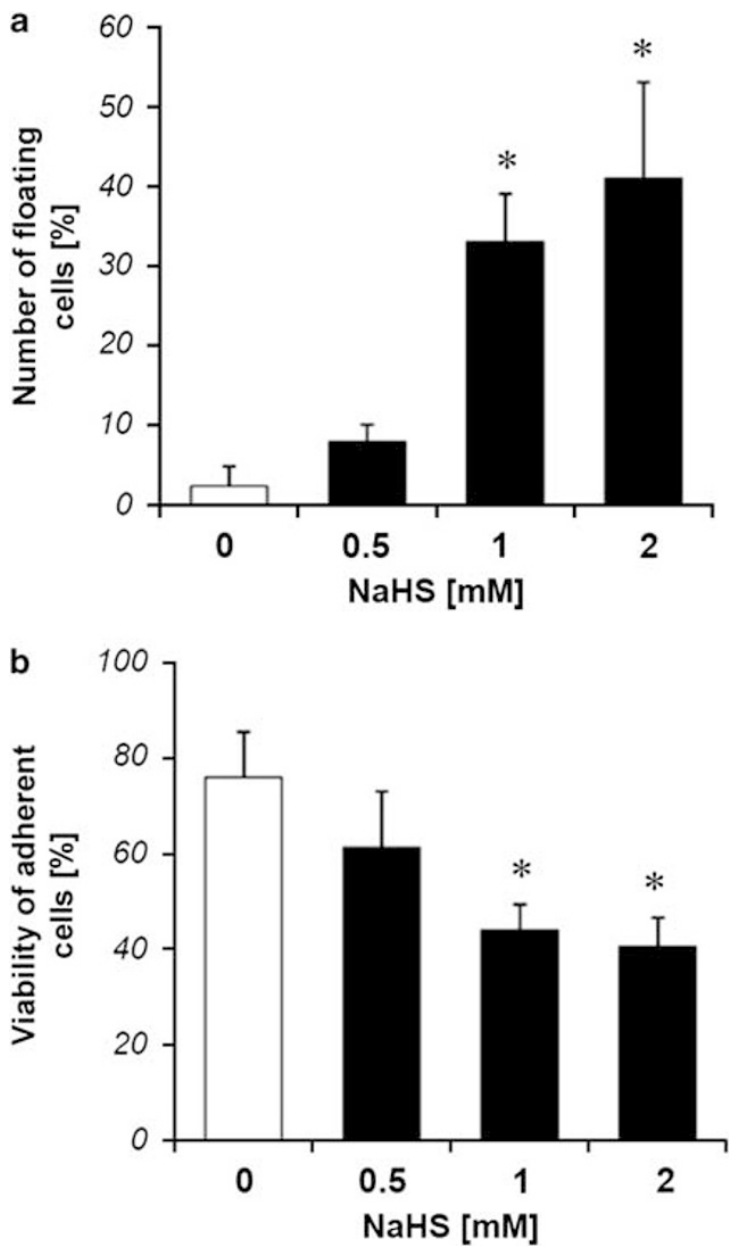

Figure $3 \mathrm{H}_{2} \mathrm{~S}$ interferes with cell adhesion and impairs cell viability of adherent cells. Differently from the experiments shown in Figure 2, in which NaHS was added to confluent NCTC cell cultures, here NaHS was added to the resuspended cells before seeding. NCTC cells were therefore allowed to adhere in the presence of the reported concentrations of NaHS. (a) The number of floating cells is reported as the percentage of total seeded cells. Means of three independent experiments \pm s.d. are shown. (b) Cell viability of adherent cells is reported as percentage of annexinV $/^{-} \mathrm{PI}^{-}$cells. ${ }^{\star} P<0.05$ Anova-Dunnet's test (treated vs untreated cells).

$54.4 \pm 13.5 \%$ of remaining adherent cells were still viable. This finding is not in contrast with the absence of toxicity shown in Figure 2a, because in these experiments cells were exposed to NaHS before adhesion.

\section{$\mathrm{H}_{2} \mathrm{~S}$ Affects the Map Kinase Signaling Axis}

Searching for the molecular mechanisms of NaHS effects, we performed a series of experiments using different pharmacological inhibitors of the key intermediates known to modulate proliferation and cell death of keratinocytes.

Colony formation was dramatically decreased by all the inhibitors used (Figure 4a). Cell adhesion of NaHS-treated NCTC was impaired as well by U0126, both in terms of increase in floating cells and decrease in adherent cell viability
(Figure $4 \mathrm{~b}$ and $\mathrm{c}$ ). Finally, the different inhibitors produced variable effects on the cell-cycle phase distribution of NCTC cell cultures (Figure 4d-f). Overall, these data suggest a role for MEK signaling in all the biological effects of NaHS; the results obtained using the PI3K inhibitor LY294002, however, also suggest the involvement of the PI3K/Akt signaling axis in some of the NaHS-induced effects. We therefore studied these two signaling pathways in greater detail.

Figure $5 \mathrm{a}$ and $\mathrm{b}$ shows that $24 \mathrm{~h}$ of $2 \mathrm{mM} \mathrm{NaHS}$ treatment neither affect the phosphorylation/activation levels of the PTEN (the major negative regulator of the PI3K-dependent signaling) nor of the Akt and the downstream GSK-3 $\beta$. NaHS did not modify the phosphorylation levels of p38 and SAPK, as well. On the contrary, as suspected by functional experiments, NaHS did impair the expression levels of pERK-1/2. We therefore analyzed the entire MAPK signaling axis (Figure $5 \mathrm{c}-\mathrm{e})$ : NaHS impaired MEK phosphorylation, and upstream pRaf-1 was dephosphorylated at ser 259, as well. Figure 5 shows the kinetic analysis of Raf (panel D), MEK (panel E) and ERK-1/2 (panel D) phosphorylation status: the dephosphorylation of Raf-MEK-ERK pathway was rapidly reached (30 min after NaHS administration) and maintained for at least $24 \mathrm{~h}$.

It is known that serine/threonine portein phosphatases 1 (PP1) and 2A (PP2A) can activate the Raf/MEK/ERK pathway by inducing the dephosphorylation of Raf- 1 at ser 259, which works as an inhibitory phosphorylation site. Moving upstream along the MAPK signaling axis, we therefore next studied the role of PP1 and PP2A in NaHS signaling. To this purpose, cells were treated with $200 \mathrm{nM}$ okadaic acid (PP1 and PP2A inhibitor). The inhibition of PP1 and PP2A prevented the Raf, MEK and ERK dephosphorylation mediated by NaHS (Figure $5 \mathrm{f}$ and g). Although okadaic acid is toxic for NCTC cell growth (at very low concentrations $(10 \mathrm{nM})$ it reduces the number of colonies), low doses of NaHS (100 and $200 \mu \mathrm{M})$ did not reduce NCTC colony formation if the cells were pretreated with $10 \mathrm{nM}$ okadaic acid (Figure 6a). Moreover, inhibition of PPT1 and PP2A (by $100 \mathrm{nM}$ okadaic acid, which shows much lower toxicity on adherent cells than on colonies) partially prevented NaHSinduced impairment of NCTC cell adhesion and BrdU incorporation (Figure 6b-d).

\section{$\mathrm{H}_{2} \mathrm{~S}$ Induces a Posttrascriptional Downmodulation of Integrins}

As cell adhesion is mediated by integrins, we finally analyzed their cell surface expression on NCTC cells. NCTC express CD49c, CD49b, CD49e, CD49f, CD104 but not CD61. Moreover, they express higher levels of $\alpha 6$ and $\alpha 2$ than of $\alpha 3$ and $\alpha 5$ integrins (see also in Table 1 ). The expression of CD104, CD49f and CD49b is bi-modal in NCTC cell cultures, each showing a bright and a dim population. NaHS $(2 \mathrm{mM}$ for $24 \mathrm{~h})$ reduced CD104, CD49b and CD49f expression (Figure 7); as expected, floating cells (red line) expressed lower levels of integrins than adherent cells. Table 1 
a

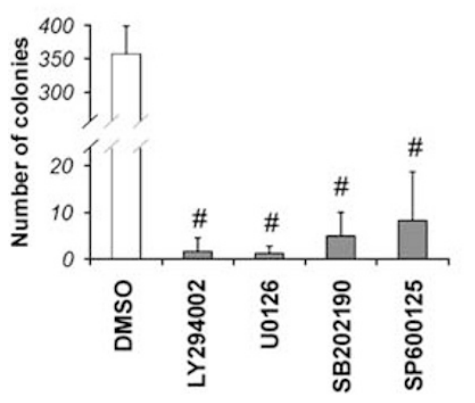

d $\quad$ Control

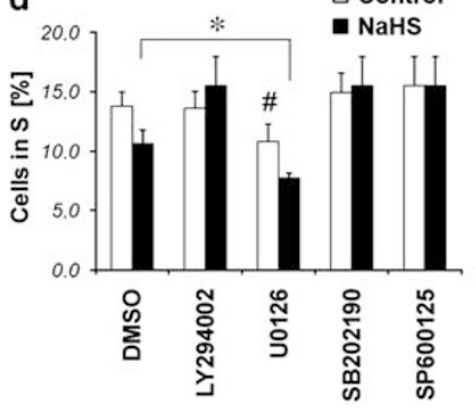

b

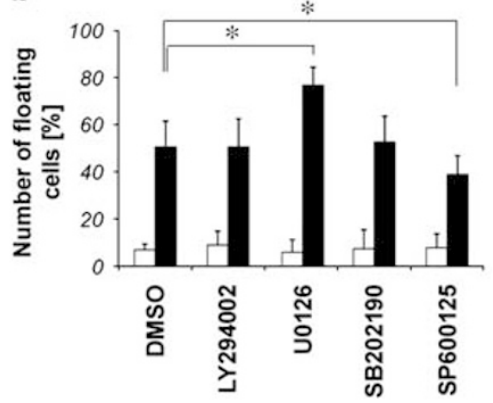

e $\quad$ a Control

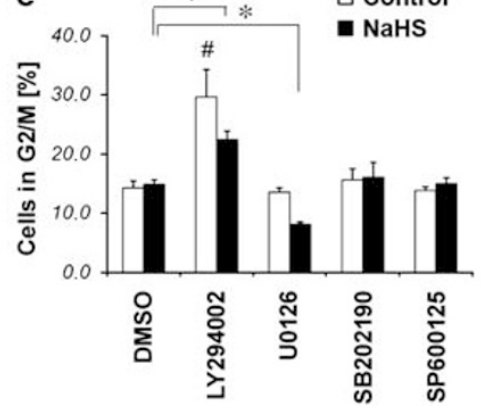

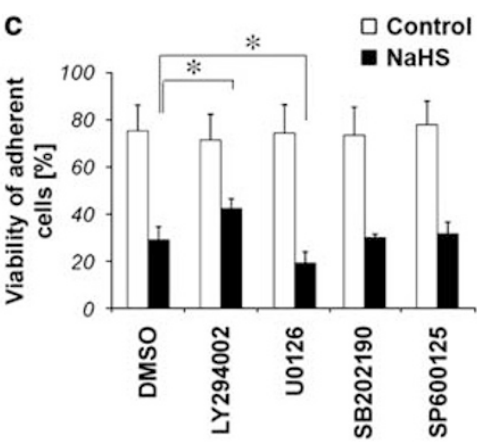

f $\quad$ Control

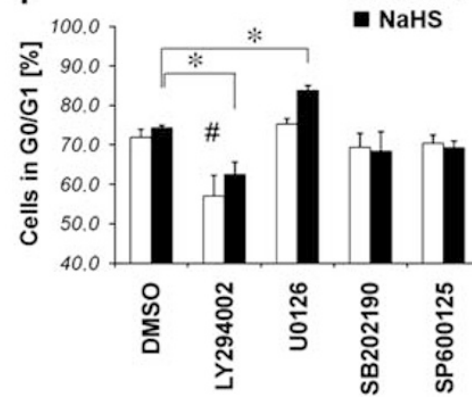

Figure 4 Effects of PI3K, p38 and ERK inhibitors on colony formation, proliferation and adhesion of NaHS-treated NCTC cells. (a) Colony formation assay: colonies obtained in the presence of LY294002, U0126, SB202190 and SP600125 are shown (gray bars). (b, c) Adhesion assay: cells were cultured for $24 \mathrm{~h}$ in the presence of the indicated inhibitors with (black bars) or without (empty bars) $2 \mathrm{mN}$ NaHS. The number of floating cells (b) and the viability of adherent cells (c) is reported. (d-f) Cell-cycle analysis after 24 h of treatment with SB202190, LY294002, U0126 and SP600125 in presence or absence of $2 \mathrm{mN}$ NaHS. The number of cells in S (d), G2/M (e) and G0/G1 cell-cycle phases (f) is reported. All data are reported as means \pm s.d. of four independent experiments. $P<0.05$ Anova-Dunnet's test (vs DMSO-treated cells); ${ }^{*} P<0.05$ Anova-Dunnet's test (vs NaHS-treated cells).

shows that NaHS reduced the number of CD49f bright adherent cells (from $89 \pm 2 \%$ to $79 \pm 6 \%$ ), and that of CD $49 b^{\text {bright }}$ adherent cells (from $89 \pm 3$ to $78 \pm 3$ ).

Cell surface expression of integrins/cell was quantified with standard fluorescent beads by flow cytometry, and reported as MESF (Table 1). No significant reduction in CD49e, CD49c expression was observed on NaHS treatment.

We asked whether the effects of $\mathrm{H}_{2} \mathrm{~S}$ on the MAPK pathway could be responsible for the observed impairment of integrin expression. Cells were allowed to adhere in the presence of $10 \mu \mathrm{M}$ U0126 or $2 \mathrm{mM} \mathrm{NaHS}$, with or without $100 \mathrm{nM}$ okadaic acid. Pretreatment with U0126 alone induced a significant reduction in $\beta 4$ (CD104), $\alpha 2$ (CD49f) and $\alpha 6$ (CD49b) integrin expression, whereas okadaic acid alone interfered only with the expression levels of $\alpha 2$. Of note, okadaic acid prevented NaHS-induced downregulation of integrins in adherent cells but not in floating cells (Figure 8).

$\mathrm{H}_{2} \mathrm{~S}$ inhibited integrin expression at the posttranscriptional level. In fact, semiquantitative RT-PCR analysis (Figure 9) showed that NaHS did not reduce the mRNA levels of $\beta 4, \alpha 2$ and $\alpha 6$ integrins.

\section{Sulfurs Deactivate ERKs in the Psoriatic Lesion}

As inhibition of ERKs represents the key event generated by NaHS in NCTC cells, we decided to test the relevance of our findings to the pathophysiology of psoriasis by immunohistochemical detection of pERKs in patient biopsies. A voluntary male affected by psoriasis was locally treated with a $2 \mathrm{mM}$ NaHS solution for 1 week, as described in 'Materials and Methods'. Very few keratinocytes from normal epidermis expressed pERK, with an exclusive cytoplasmic localization (Figure 10e and f). On the contrary, pERKs were strongly expressed in the keratinocytes of the psoriatic lesion, with both a cytoplasmic and nuclear localization (Figure 10a and b). Of note, NaHS reduced ERK activation levels in the lesion, in which overall pERK expression was downregulated, with a dramatic decrease in its nuclear localization (Figure $10 \mathrm{c}$ and $\mathrm{d}$ ).

\section{DISCUSSION}

Recently, $\mathrm{H}_{2} \mathrm{~S}$ has attracted major scientific interest as a novel inorganic gaseous mediator involved in various physiological and pathological conditions. Notwithstanding the existing reports on the effects of sulfur compounds in psoriasis, little is known about their effects on the keratinocyte, the key cell type in the pathophysiology of this disease. ${ }^{15}$

Our data show that NaHS impairs keratinocytes proliferation and clonal growth. In agreement with Lee et $a l^{32}$ we found that $\mathrm{H}_{2} \mathrm{~S}$ interferes with keratinocytes proliferation, reducing DNA synthesis and progression through the $S$ 

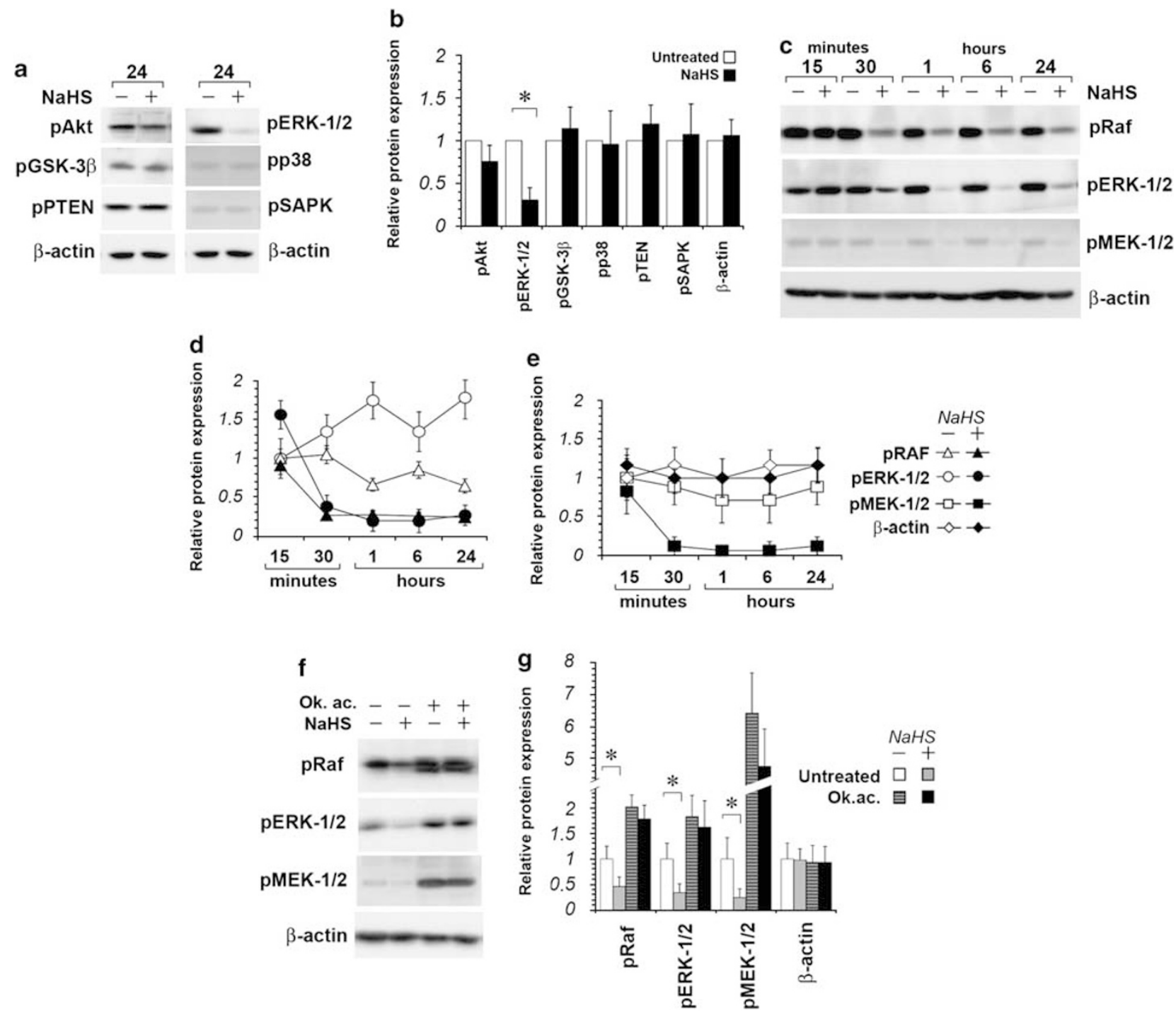

Figure 5 NaHS impairs Raf/MEK/ERK phosphorylation. Western blot analysis of PI3K/Akt and MAPK signaling pathways. (a, b) NCTC cells were treated with $(+)$ or without $(-) 2 \mathrm{mM}$ NaHS for $24 \mathrm{~h}$. Total proteins were immunoblotted for the detection of pAkt, pGSK-3 $\beta$, pPTEN, pERK-1/2, pp38 and pSAPK. Sulfurs selectively downregulate the expression levels of pERKs. (c-e) Kinetic analysis of NaHS effects on Raf, MEKs and ERKs phosphorylation levels. NCTC cells were treated with $(+)$ or without $(-) 2 \mathrm{mM} \mathrm{NaHS}$ and pRaf, pMEKs and pERKs levels were detected at the indicated times. (f, $\mathbf{g})$ Cells were treated with or without $200 \mathrm{nM}$ okadaic acid for $24 \mathrm{~h}$, then treated with or without $2 \mathrm{mM}$ NaHS for $3 \mathrm{~h}$. Phosphorylation levels of Raf, MEK and ERK are reported. Statistics: means of three independent experiments \pm s.d. are reported. ${ }^{\star} P<0.05 t$-test.

phase. At the molecular level, we show that $\mathrm{H}_{2} \mathrm{~S}$ reduces the Raf/MEK/ERK signaling pathway decreasing the phosphorylation levels of ERK-1/2 and of the upstream MEK kinase. The mechanism is phosphatase-dependent, as okadaic acidmediated inhibition of phosphatases prevents pERK and pMEK downmodulation.

Looking deeper in the molecular mechanism of sulfurinduced effects, with some surprise we found that NaHS induced the activation of Raf- 1 by promoting Raf- 1 ser 259 dephosphorylation. Raf is the apical protein of a specific signaling pathway: in quiescent cells Raf- 1 is locked in an inactive conformation by the phosphorylation of ser259 in the regulatory domain. During Raf-1 activation, the dephosphorylation of ser259 is mediated by PP1 and/or PP2A as part of the membrane recruitment step. MEK-1 and -2 are activated by the phosphorylation on two serine residues by Raf. ERK-1 and -2 are, in turn, activated by MEK-1 and -2, by the phosphorylation of a tyrosine and a threonine residue within the activation loop of the protein. PP1 and PP2A can also regulate MEK and ERK deactivation, directly promoting tyrosine dephosphorylation. ${ }^{33,34}$ Therefore, we reasoned that PP1 and PP2A might be responsible for the simultaneous dephosphorylation of MEK, ERK and Raf. We show that NaHS induced the dephosphorylation of both pMEKs and 

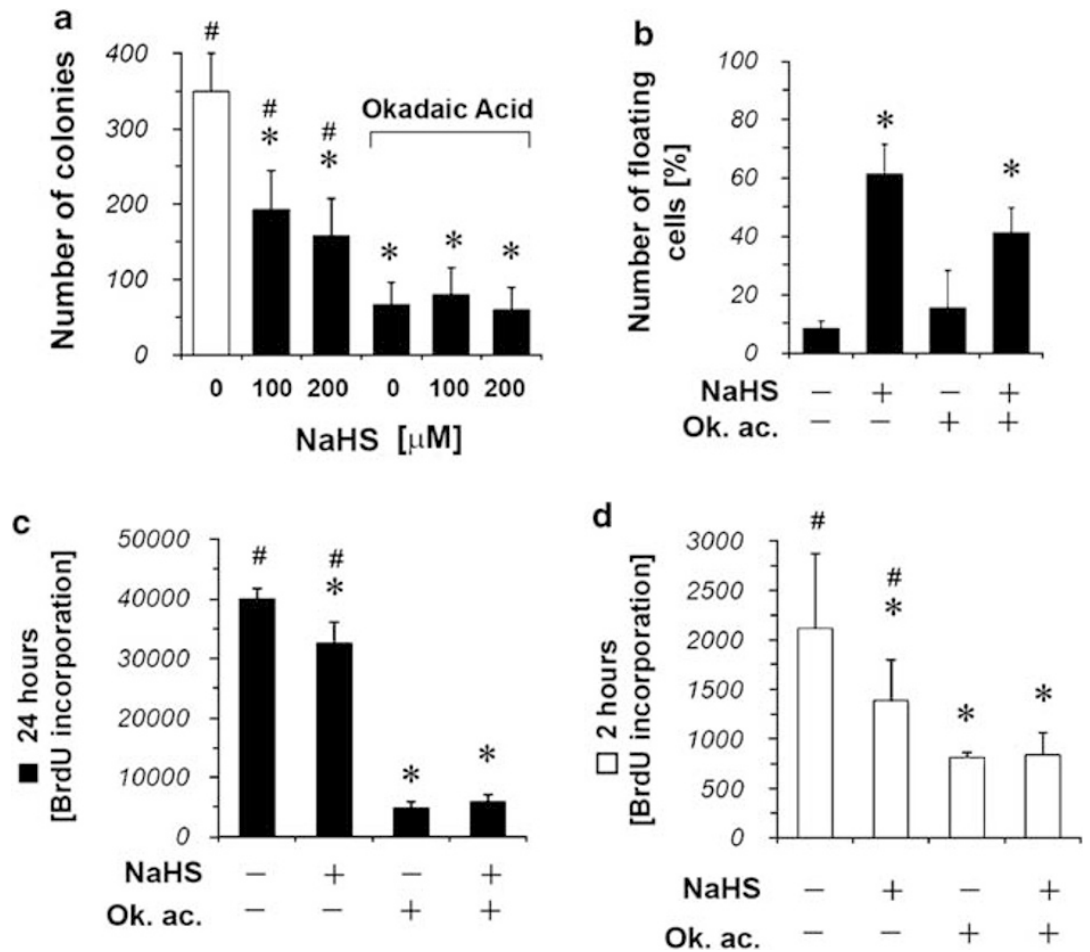

Figure 6 Okadaic acid prevents NaHS effects. (a) Colony formation assay. NCTC cells were cultured in the presence of the reported concentrations of NaHS; $10 \mathrm{nM}$ okadaic acid was added for $24 \mathrm{~h}$ post seeding. Empty bar: number of colonies obtained in untreated cultures (control). (b) Adhesion assay: cells treated with or without $100 \mathrm{mM}$ okadaic acid were allowed to adhere for $24 \mathrm{~h}$ in the presence or absence of $2 \mathrm{mM}$ NaHS. The number of floating cells was scored by flow cytomery analysis. (c, d) DNA synthesis of nonsynchronized NCTC cells treated with or without $100 \mathrm{nM}$ okadaic acid. Short-time treatment ( $2 \mathrm{~h}$, empty bars) and long-time treatment ( $24 \mathrm{~h}$, black bars) with NaHS $(2 \mathrm{mM})$ reduced BudU incorporation. Statistics: means of three independent experiments \pm s.d. are reported. ${ }^{*} P<0.05$ Anova-Dunnet's test (vs control cultures). $P<0.05$ Anova-Dunnet's test (vs okadaic-treated and NaHS-untreated cultures).

Table 1 Cell surface expression of integrins in NCTC cells treated with $2 \mathrm{mM}$ NaHS for $24 \mathrm{~h}$

\begin{tabular}{|c|c|c|c|c|c|c|}
\hline Integrin & \multicolumn{3}{|c|}{ Antigen expression level (MESF) } & \multicolumn{3}{|c|}{ Cells with bright positivity (\%) } \\
\hline$\beta 4(C D 104)$ & $57804 \pm 5125^{\#}$ & $50376 \pm 4089^{*}$ & $30850 \pm 2460^{* \#}$ & $80 \pm 5$ & $73 \pm 9$ & $52 \pm 17^{*}$ \\
\hline$\alpha 3(\mathrm{CD} 49 \mathrm{c})$ & $29864 \pm 6039$ & $26686 \pm 6627$ & $28523 \pm 2122$ & ND & ND & ND \\
\hline$\alpha 5$ (CD49e) & $27215 \pm 5240$ & $25784 \pm 2341$ & $30203 \pm 3316$ & ND & ND & ND \\
\hline
\end{tabular}

Reported values are mean \pm s.d. of four independent experiments.

Statistic: ${ }^{\#} P<0.05$ vs adherent NaHS-treated cells, ${ }^{*} P<0.05$ vs control.

ND: not detectable two subpopulations with dim and bright fluorescence.

pERKs. This activity seemed specific, as pPTEN, pAkt, pGSK$3 \beta$ and also pp38 and pJNK phosphorylation levels were not affected at all by NaHS. From the functional point of view, in agreement with data from other groups, ${ }^{35-37}$ MEK inhibition (by U0126) suggested that the MEK-ERK signaling has a major role in the control of NCTC cell proliferation.

The antiproliferative effects of NaHS are now well documented at least in lymphocytes in vitro ${ }^{38-39}$ and in smooth 

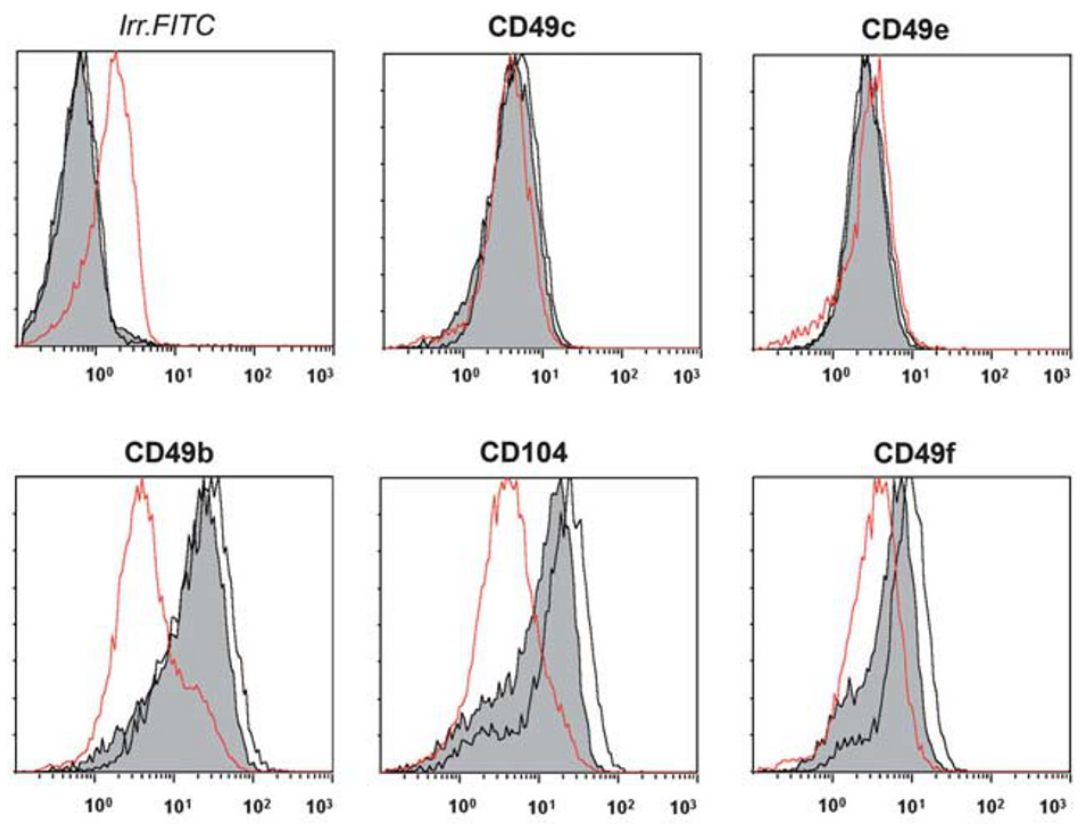

\section{$\square+$ HS floating cells \\ +HS adherent cells \\ Control (adherent cells)}

Figure 7 Cell surface expression of integrins. Flow cytometry detection of cell surface expression of CD49c, CD49e, CD49b, CD104 and CD49f on NCTC cells seeded in the presence of $2 \mathrm{mM}$ NaHS. After $24 \mathrm{~h}$, floating cells from treated cultures show lower levels of CD49b, CD104 and CD49f expression (empty histograms, red line) as compared to adherent cells (gray filled histograms) and to adherent cells from control cultures (empty histograms, black line). Isotype-matched irrelevant antibody fluorescence (Irr.FITC) was used as control.

muscle cell during injury-induced neointimal hyperplasia in vivo. ${ }^{40}$ However, at variance to what we observe here, $\mathrm{H}_{2} \mathrm{~S}$ antiproliferative signaling has been correlated to ERK activation in HEK293 cells ${ }^{41}$ and to increased c-Jun, Raf, MAPKK, MEK and ERK mRNA expression levels in IEC-18 rat intestinal cells. ${ }^{15}$ The effects of sulfurs on keratinocytes, however, seem more complex, as the role of several survival/ proliferation pathways produce different effects on adherent or nonadherent cells: (i) neither inhibition of ERKs nor p38 activation is sufficient to reduce cell viability of nonadherent NCTC cells or to interfere with their adhesion, however, U0126 increases cell death of NaHS-treated adherent cells; (ii) sulfurs do not modulate the PI3K pathway in NCTC cells, however, LY294002 abolished colony formation, reduced S phase and partially prevented cell death of NaHS-treated adherent NCTC. To this respect, it must be considered that in addition to its pro-survival function, Akt has also been involved in various cellular processes as migration, proliferation and maturation. In case of signaling-defective $\beta 4$-integrin, cellular stresses such as starvation result in apoptosis. This implies that under circumstances requiring high Akt activity, such as stress, the Akt pool becomes limiting in the absence of $\beta 4$-integrin signaling. ${ }^{42}$ Moreover, in human keratinocytes, JNK-activated c-Jun has been found to control the proliferative activity downstream $\beta 4$-integrin and EGF-R activation. ${ }^{42,43}$ Therefore, while searching for the molecular basis of the observed interactions between sulfurs and the PI3K pathway in keratinocytes, we ended up with integrins. NaHS-induced reduction of $\beta 4$-integrin expression on NCTC cells can explain both cell death and inhibition of clonal growth. In fact (i) NCTC cells, stressed by trypsinization, strongly depend on Akt levels for survival: in this situation, inhibition of PI3K by LY294002 promotes cell death; and (ii) low integrin expression prevents clonogenic cells to adhere and form colonies, like epithelial cells that die by apoptosis when forced to grow under anchorage-independent conditions. $^{23}$

In summary, we hypothesize that the very first mechanism by which exogenous NaHS interferes with keratinocytes clonal growth and survival is the inhibition of integrin expression. In human and mouse epidermis, keratinocytes express $\alpha 6 \beta 4$ (laminin-5 receptor), $\alpha 2 \beta 1$ (collagen I receptor), $\alpha 3 \beta 1$ (laminin-5 receptor) and $\alpha \mathrm{v} \beta 5$ (vitronectin receptor) integrins, ${ }^{23,24}$ which contribute to their anchorage to the basal membrane in situ. NaHS selectively downregulates the expression of both components $(\alpha 6 \beta 4)$ of laminin-5 receptor and that of $\alpha 2$ integrin (CD49b), subunit of the type I collagen receptor. $\alpha 6 \beta 4$ has several functions: it allows stable cell-to-cell and cell-to-basal membrane adhesion, promotes keratinocyte migration and activates signaling pathways that 

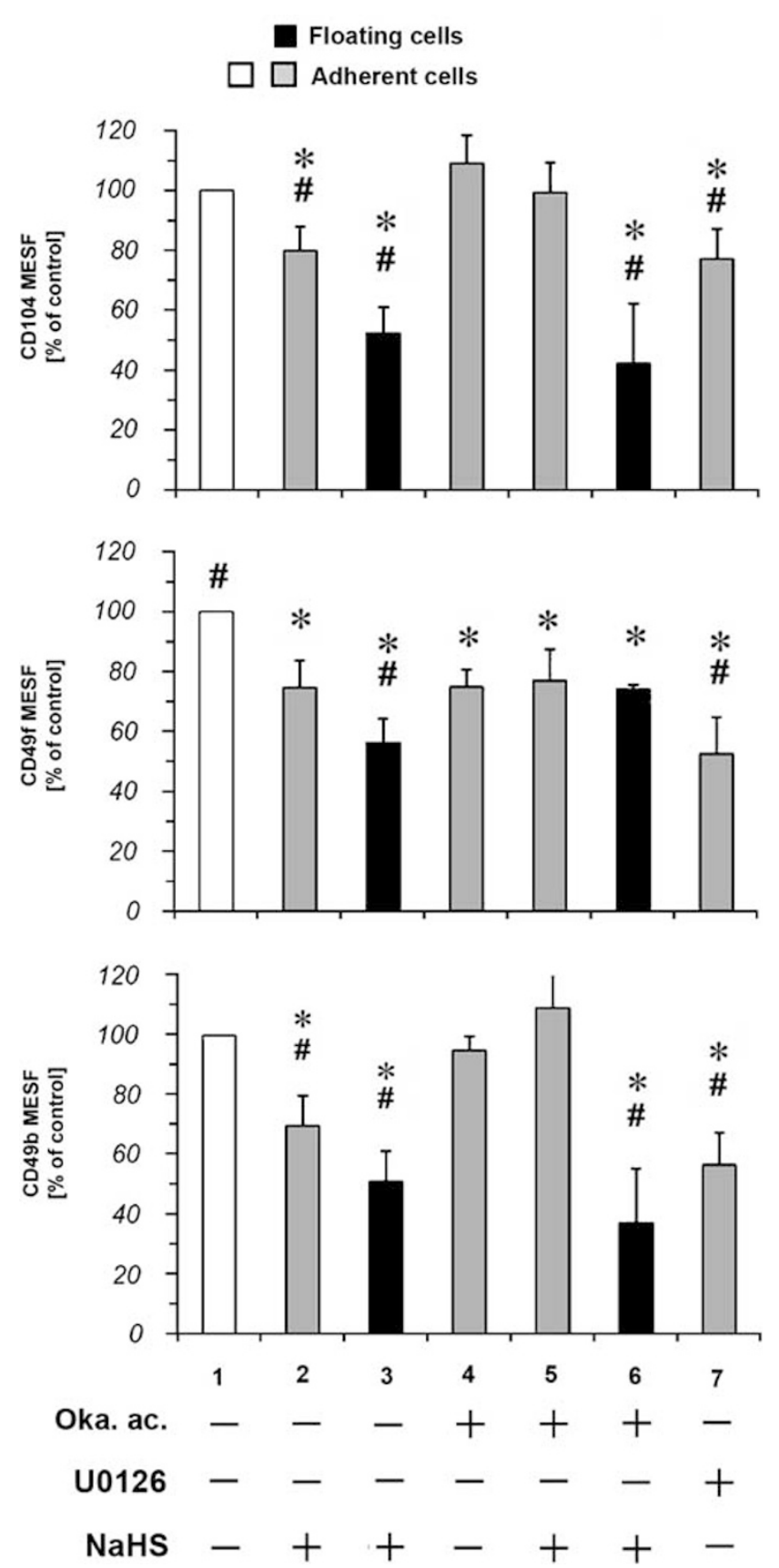

Figure 8 Role of MAK in NaHS-induced downregulation of integrin expression. Flow cytometry quantification of cell surface expression of CD104, CD49f and CD49b on NCTC cells treated with $10 \mu \mathrm{M}$ U0126, $100 \mathrm{nM}$ okadaic acid, seeded in the presence of $2 \mathrm{mM}$ of NaHS. Twenty-four hours later, floating cells (black bars) and adherent cells (gray bars) were analyzed. MESF values (means \pm s.d. of three independent experiments) are reported as percentages of control values (empty bar). ${ }^{\star} P<0.05$ Anova-Dunnet's test (vs lane 1). $P<0.05$ Anova-Dunnet's test (vs lane 4).

are synergistic with those of growth factor receptors. ${ }^{25}$ More in general, $\alpha 6 \beta 4$ is necessary for tumor cell invasion, cooperates with $c$-met in the transformation of rodent fibroblasts and is necessary to maintain the tumorigenic phenotype of carcinoma cells. ${ }^{44}$ Thus, the ability of NaHS to

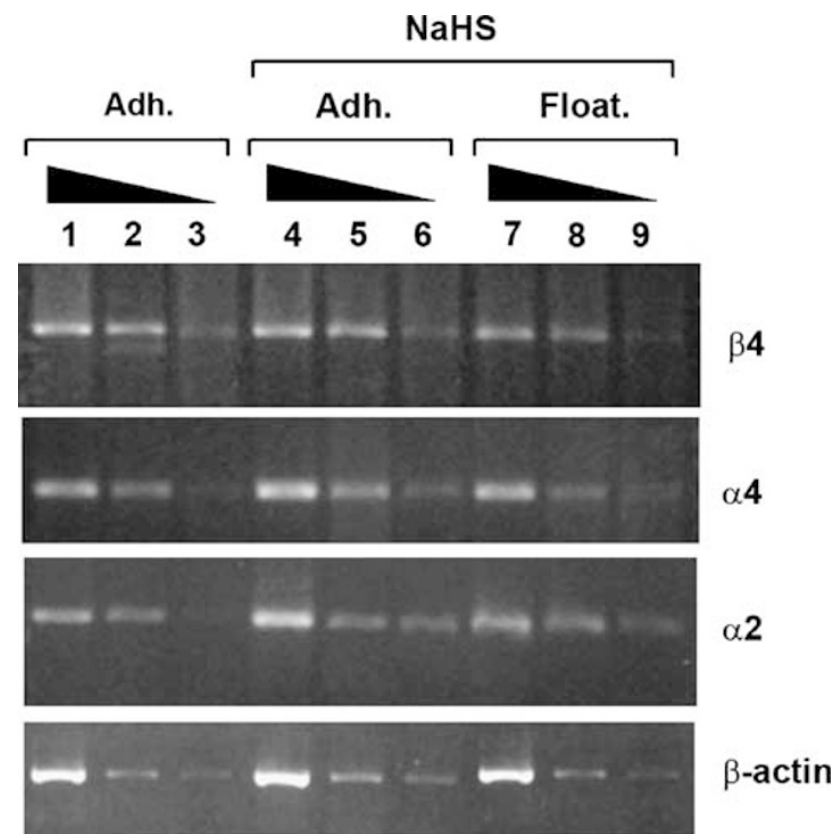

Figure $9 \mathrm{NaHS}$ does not affect the transcription levels of integrins. Semiquantitative RT-PCR analysis of adherent (Adh.) and floating (Float.) cells from NCTC cultures treated for $24 \mathrm{~h}$ with $2 \mathrm{mM}$ NaHS. Expression of CD104 ( $\beta 4), \operatorname{CD} 49 f(\alpha 4), \mathrm{CD} 49 \mathrm{~b}(\alpha 2)$ and $\beta$-actin from a representative experiment is reported. CDNA dilutions: $1 / 10$ (lanes 1,4 and 7); $1 / 100$ (lanes 2, 5 and 8); 1/1000 (lanes 3, 6 and 9).

inhibit the expression of $\alpha 6 \beta 4$ can be reasonably considered relevant in the control of keratinocyte growth and adhesion.

Sulfurs are able to penetrate the skin, and a sulfur-rich balneotherapy is known to be effective in the treatment of psoriasis. ${ }^{22}$ This is the reason why we used NaHS at concentrations that are higher than those of endogenously produced HS $^{-}$, but comparable to those found in most natural sources of sulfurs. According to earlier studies, keratinocytes of hyperplastic epidermis express high levels of pERK with the classical nuclear localization, whereas keratinocytes of normal skin show low pERKs levels with a main cytoplasmic localization. ${ }^{45-47}$ We have topically treated a psoriatic lesion with NaHS at the same concentration found in most balneotherapies. This treatment clearly reduced pERKs expression in the lesion, both at nuclear and cytoplasmic levels. Considering that we have shown earlier that sulfurs have subset-specific toxicity on CD8 + lymphocytes, ${ }^{21}$ another major player in the complex pathophysiology of psoriasis, studies are in progress to evaluate the effects of $\mathrm{NaHS}$ in the development/progression of psoriasis.

It must be underlined that as negative control we used the nonpsoriatic skin of a psoriatic patient. No definitive proof of the absence of detrimental effects on normal skin is, therefore, provided here. However, the $\mathrm{HS}^{-}$concentration that we use is comparable to that of most natural sources, and to our knowledge no adverse effect on skin has been directly related to sulfurous balneotherapy to date. 

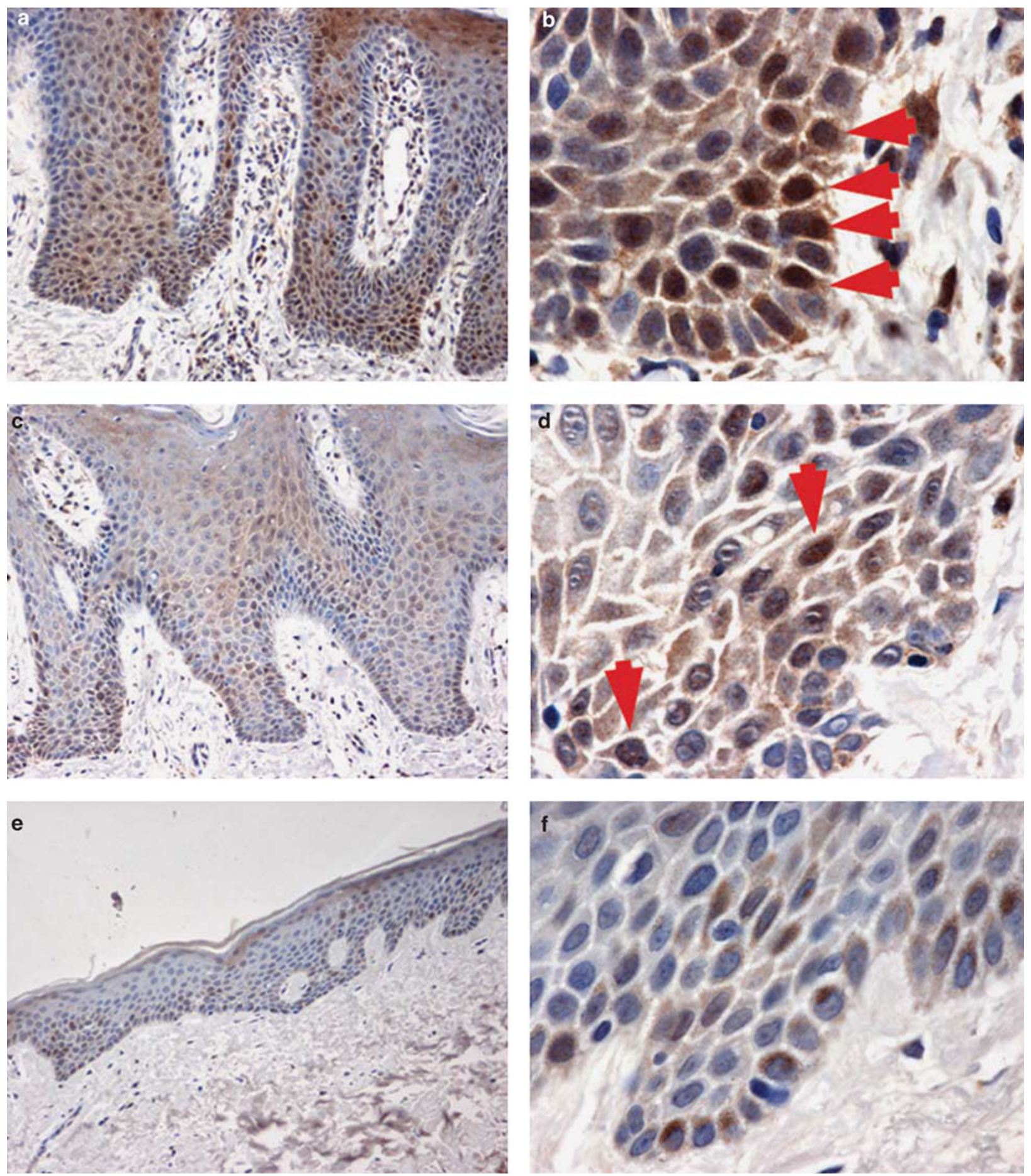

Figure 10 : NaHS reduces ERKs activation in vivo. Immunohistochemistry detection of pERK-1/2 in human skin of a patient affected by psoriasis. Biopsies of lesioned (a-d) and normal skin (e, f) from the same patient. (a, b) PBS-treated skin; (c, d) NaHS-treated skin; (e, f) normal, untreated skin. (a, c, e) Original magnification $\times 20$. $(\mathbf{b}, \mathbf{d}, \mathbf{f})$ pERK-1/2 detection at higher magnification $(\times 100)$. Red arrows: cells with nuclear pERK-1/2 expression. No cells with nuclear localization of pERK-1/2 were detected in normal skin.

We believe that the understanding the molecular events generated by sulfurs on inflammatory cells and keratinocytes will explain their clinically relevant beneficial effects on psoriatic lesions, that up to now are confined to the mere observational level.

\section{ACKNOWLEDGEMENTS}

CM is supported by a fellowship grant from Terme di Sirmione, Brescia, Italy. This study was supported in part by 'Fondazione per la Ricerca Scientifica Termale' grant to GdP and by MUR -COFIN 2006; FIL 2007 (FIL0719884). We are grateful to Instrumentation Laboratory, Italy, for technical support. 
1. Kamoun P. Endogenous production of hydrogen sulfide in mammals. Amino Acids 2004;26:243-254.

2. Finkelstein JD, Martin JJ. Methionine metabolism in mammals. Distribution of homocysteine between competing pathways. J Biol Chem 1984;259:9508-9513.

3. Navarra P, Dello Russo C, Mancuso C, et al. Gaseous neuromodulators in the control of neuroendocrine stress axis. Ann N Y Acad Sci 2000;917:638-646.

4. Moore PK, Bhatia M, Moochhala S. Hydrogen sulfide: from the smell of the past to the mediator of the future? Trends Pharmacol Sci 2003;24:609-611.

5. Wang R. Two's company, three's a crowd: can $\mathrm{H}_{2} \mathrm{~S}$ be the third endogenous gaseous transmitter? FASEB J 2002;16:1792-1798.

6. Eto $\mathrm{K}$, Ogasawara $\mathrm{M}$, Umemura $\mathrm{K}$, et al. Hydrogen sulfide is produced in response to neuronal excitation. J Neurosci 2002;22:3386-3391.

7. Zhao W, Zhang J, Lu Y, et al. The vasorelaxant effect of $\mathrm{H}(2) \mathrm{S}$ as a novel endogenous gaseous K(ATP) channel opener. EMBO J 2001;20:6008-6016.

8. Teague B, Asiedu S, Moore PK. The smooth muscle relaxant effect of hydrogen sulphide in vitro: evidence for a physiological role to control intestinal contractility. Br J Pharmacol 2002;137:139-145.

9. Du J, Hui $Y, C$ Cheung $Y$, et al. The possible role of hydrogen sulfide as a smooth muscle cell proliferation inhibitor in rat cultured cells. Heart Vessels 2004;19:75-80.

10. Qingyou Z, Junbao D, Weijin Z, et al. Impact of hydrogen sulfide on carbon monoxide/heme oxygenase pathway in the pathogenesis of hypoxic pulmonary hypertension. Biochem Biophys Res Commun 2004;317:30-37.

11. Oh GS, Pae HO, Lee BS, et al. Hydrogen sulfide inhibits nitric oxide production and nuclear factor-kappaB via heme oxygenase-1 expression in RAW264.7 macrophages stimulated with lipopolysaccharide. Free Radic Biol Med 2006;41:106-119.

12. Deplancke B, Gaskins HR. Hydrogen sulfide induces serumindependent cell cycle entry in nontransformed rat intestinal epithelial cells. FASEB J 2003;17:1310-1312.

13. Collin $M$, Anuar FB, Murch $O$, et al. Inhibition of endogenous hydrogen sulfide formation reduces the organ injury caused by endotoxemia. Br J Pharmacol 2005;146:498-505.

14. Mok YY, Atan MS, Yoke Ping C, et al. Role of hydrogen sulphide in haemorrhagic shock in the rat: protective effect of inhibitors of hydrogen sulphide biosynthesis. Br J Pharmacol 2004;143:881-889.

15. Szabó C. Hydrogen sulphide and its therapeutic potential. Nat Rev Drug Discov 2007;6:917-935.

16. Hu Y, Chen X, Pan $\Pi$, et al. Cardioprotection induced by hydrogen sulfide preconditioning involves activation of ERK and PI3K/Akt pathways. Pflugers Arch 2008;455:607-616.

17. Pan $\Pi$, Neo KL, Hu LF, et al. $\mathrm{H} 2 \mathrm{~S}$ preconditioning-induced PKC activation regulates intracellular calcium handling in rat cardiomyocytes. Am J Physiol Cell Physiol 2008;294:C169-C177.

18. Sivarajah $A$, Collino $M$, Yasin $M$, et al. Anti-apoptotic and antiinflammatory effects of hydrogen sulfide in a rat model of regional myocardial I/R. Shock 2009;31:267-274.

19. Adhikari S, Bhatia M. H2S-induced pancreatic acinar cell apoptosis is mediated via JNK and p38 MAP kinase. J Cell Mol Med 2008;12: 1374-1383.

20. Rinaldi L, Gobbi G, Pambianco M, et al. Hydrogen sulfide prevents apoptosis of human PMN via inhibition of p38 and caspase 3. Lab Invest 2006;86:391-397.

21. Mirandola P, Gobbi G, Sponzilli I, et al. Exogenous hydrogen sulfide induces functional inhibition and cell death of cytotoxic lymphocytes subsets. J Cell Physiol 2007;213:826-833.

22. Matz H, Orion E, Wolf R. Balneotherapy in dermatology. Dermatol Ther 2003;16:132-140.

23. Frisch $\mathrm{SM}$, Francis $\mathrm{H}$. Disruption of epithelial cell-matrix interactions induces apoptosis. J Cell Biol 1994;124:619-626.

24. Watt FM. Role of integrins in regulating epidermal adhesion, growth and differentiation. EMBO J 2002;21:3919-3926.
25. Wilhelmsen $\mathrm{K}$, Litjens $\mathrm{SH}$, Sonnenberg A. Multiple functions of the integrin alpha6beta4 in epidermal homeostasis and tumorigenesis. Mol Cell Biol 2006;26:2877-2886.

26. Kamstrup MR, Gniadecki R, Skovgaard GL. Putative cancer stem cells in cutaneous malignancies. Exp Dermatol 2007;16:297-301.

27. Schwartz A, Fernández Repollet E, Vogt R, et al. Standardizing flow cytometry: construction of a standardized fluorescence calibration plot using matching spectral calibrators. Cytometry 1996;26:22-31.

28. Merighi $S$, Mirandola $P$, Milani $D$, et al. Adenosine receptors as mediators of both cell proliferation and cell death of cultured human melanoma cells. J Invest Dermatol 2002;119:923-933.

29. Vitale M, Pelusi G, Taroni B, et al. HLA class I antigen down-regulation in primary ovary carcinoma lesions: association with disease stage. Clin Cancer Res 2005;11:67-72.

30. Mirandola P, Sponzilli I, Solenghi E, et al. Down-regulation of human leukocyte antigen class I and II and beta 2-microglobulin expression in human herpesvirus-7-infected cells. J Infect Dis 2006;193:917-926.

31. De Panfilis G, Campanini N, Santini M, et al. Phase- and stage-related proportions of $\mathrm{T}$ cells bearing the transcription factor FOXP3 infiltrate primary melanoma. J Invest Dermatol 2008;128:676-684.

32. Lee J, Lee HJ, Park JD, et al. Anti-cancer activity of highly purified sulfur in immortalized and malignant human oral keratinocytes. Toxicol In Vitro 2008;22:87-95.

33. Hunter T. Protein kinases and phosphatases: the yin and yang of protein phosphorylation and signaling. Cell 1995;80:225-236.

34. Junttila MR, Li SP, Westermarck J. Phosphatase-mediated crosstalk between MAPK signaling pathways in the regulation of cell survival. FASEB J 2008;22:954-965.

35. Dajee $M$, Tarutani $M$, Deng $H$, et al. Epidermal Ras blockade demonstrates spatially localized Ras promotion of proliferation and inhibition of differentiation. Oncogene 2002;21:1527-1538.

36. Tarutani M, Cai T, Dajee M, et al. Inducible activation of Ras and Raf in adult epidermis. Cancer Res 2003;63:319-323.

37. Hobbs RM, Silva-Vargas V, Groves R, et al. Expression of activated MEK1 in differentiating epidermal cells is sufficient to generate hyperproliferative and inflammatory skin lesions. J Invest Dermatol 2004;123:503-515.

38. Valitutti S, Castellino F, Musiani P. Effect of sulfurous (thermal) water on T lymphocyte proliferative response. Ann Allergy 1990;65: 463-468.

39. Mirandola P, Gobbi G, Sponzilli I, et al. Exogenous hydrogen sulfide induces functional inhibition and cell death of cytotoxic lymphocytes subsets. J Cell Physiol 2007;213:826-833.

40. Meng QH, Yang G, Yang W, et al. Protective effect of hydrogen sulfide on balloon injury-induced neointima hyperplasia in rat carotid arteries. Am J Pathol 2007;170:1406-1414.

41. Yang G, Cao K, Wu L, et al. Cystathionine gamma-lyase overexpression inhibits cell proliferation via a H2S-dependent modulation of ERK1/2 phosphorylation and p21Cip/WAK-1. J Biol Chem 2004;279: 49199-49205.

42. Müller EJ, Williamson L, Kolly $C$, et al. Outside-in signaling through integrins and cadherins: a central mechanism to control epidermal growth and differentiation? J Invest Dermatol 2008;128:501-516.

43. Meredith Jr JE, Schwartz MA. Integrins, adhesion and apoptosis. Trends Cell Biol 1997;7:146-150.

44. Bertotti A, Comoglio PM, Trusolino L. Beta4 integrin is a transforming molecule that unleashes Met tyrosine kinase tumorigenesis. Cancer Res 2005;65:10674-10679.

45. Yu XJ, Li CY, Dai HY, et al. Expression and localization of the activated mitogen-activated protein kinase in lesional psoriatic skin. Exp Mol Pathol 2007;83:413-418.

46. Johansen C, Kragballe K, Westergaard $M$, et al. The mitogen-activated protein kinases p38 and ERK1/2 are increased in lesional psoriatic skin. Br J Dermatol 2005;152:37-42.

47. Takahashi $\mathrm{H}$, Ibe $\mathrm{M}$, Nakamura $\mathrm{S}$, et al. Extracellular regulated kinase and c-Jun N-terminal kinase are activated in psoriatic involved epidermis. J Dermatol Sci 2002;30:94-99. 